\title{
Obowiązek ewidencji i opodatkowanie działalności gospodarstw rolnych
}

\section{Wstęp}

Działalność gospodarstw rolnych jest obecnie objęta podatkiem rolnym. Proponowane nowe rozwiązanie opodatkowania działalności tychże gospodarstw podatkiem dochodowym nie powinno spowodować dodatkowego obciążenia rolników, gdyż ma on zastąpić istniejący obowiązek płatności podatku rolnego. Według Ministerstwa Finansów, obciążenie w postaci podatku dochodowego stanowi związanie podatku z rzeczywistymi dochodami rolników. Stosowane obecnie opodatkowanie działalności w rolnictwie nie jest uzależnione ani od efektywności wykorzystania powierzchni rolnej, ani od wniesionej pracy, ani też poniesionych nakładów.

Wprowadzenie podatku dochodowego w rolnictwie zdaniem ekspertów zintegruje w większym stopniu społeczeństwo i zwiększy poczucie sprawiedliwości podatkowej. Zawsze likwidacja uprzywilejowań niektórych grup jest aprobowana przez społeczeństwo i ma na nie pozytywny wpływ. W czasach kryzysu sytuacje, gdy wszyscy ponoszą koszty, powodują większą skłonność społeczeństwa do wyrzeczeń.

Zdecydowana większość krajów członkowskich UE zastosowała opodatkowanie działalności rolniczej podatkiem dochodowym na zasadach podobnych do obowiązujących przy opodatkowaniu działalności gospodarczej, a od wysokości dochodów gospodarstw rolnych uzależniony jest sposób ich opodatkowania.

Zmiana opodatkowania $w$ rolnictwie, $w$ opinii ekonomistów, jest konieczna $\mathrm{i}$ ten fakt nie budzi wątpliwości. Rodzi się tu jednak pytanie: jakie będą z tego tytułu konsekwencje dla budżetu państwa, a w zasadzie dla budżetów gmin, gdyż podobnie jak podatek rolny, podatek dochodowy od działalności rolniczej ma być źródłem dochodu jednostek samorządów terytorialnych. 
Środowisko rolnicze sceptycznie podchodzi do wprowadzenia nowych zasad opodatkowania ich działalności. Większość z nich twierdzi, że będzie to znaczne obciążenie, o wiele wyższe niż dotychczasowy podatek rolny. Czy jednak tak będzie w rzeczywistości? Brak danych o dochodach gospodarstw rolnych powoduje, że jest to jedna wielka niewiadoma. Wprawdzie istnieje system FADN ${ }^{1}$ dokonujący ewidencji działalności gospodarstw rolnych (około 11 tys.) ${ }^{2}$, funkcjonujący na zasadzie dobrowolności ewidencji, ale czy można uogólniać wyniki tych gospodarstw na całość populacji liczącej blisko 2 miliony osób? A ponadto, na ile informacje $\mathrm{z}$ tych gospodarstw są wiarygodne?

Autorka w artykule stawia za cel poznanie opinii rolników w zakresie wprowadzenia podatku dochodowego w rolnictwie, a w szczególności obowiązku ewidencji, a także przybliżenie i analizę proponowanego rozwiązania opodatkowania podatkiem dochodowym oraz problemu ewidencji działalności gospodarstw rolnych. Jednym z narzędzi realizacji celu jest analiza aktualnych przepisów prawnych i proponowanych zmian oraz poglądów naukowców i praktyków życia gospodarczego. Drugim z kolei jest analiza opinii rolników w kwestii opodatkowania i ewidencji działalności gospodarstw rolnych. Badaniu poddano grupe 120 rolników z centralnych i wschodnich regionów Polski. Badaniu poddano także grupę 20 małych biur rachunkowych w tych regionach $\mathrm{w}$ celu uzyskania informacji $\mathrm{w}$ kwestii usług prowadzenia ewidencji zdarzeń gospodarczych w rolnictwie.

Niniejszy artykuł jest wstępem do dalszych badań autorki w zakresie zagadnienia rachunkowości i opodatkowania gospodarstw rolniczych.

\section{Podatki w rolnictwie - stan aktualny}

Podatek rolny jest jednym z elementów systemu opodatkowania działalności podmiotów gospodarczych, a w szczególności gospodarstw rolnych. Wprowadzony ustawą o podatku rolnym ${ }^{3}$ zastapił podatek gruntowy o charakterze progresywnym, istniejący od 1946 roku. Podstawą obliczenia podatku rolnego jest suma wartości użytkowej danych gruntów ustalana w wyniku

\footnotetext{
${ }^{1}$ FADN - Sieć Danych Rachunkowości Gospodarstw Rolnych, czyli FADN (ang. Farm Accountancy Data Network) oraz RICA (franc. Reseau D'information Comptable Agricole).

2 Próba reprezentatywna polskiego FADN w województwach mazowieckim, wielkopolskim, małopolskim oraz pomorskim i lubuskim, patrz: L. Goraj, S. Mańko, 2009: Rachunkowość i analiza ekonomiczna w indywidualnym gospodarstwie rolnym, Wydawnictwo Difin, Warszawa, s. 56.

${ }^{3}$ Ustawa o podatku rolnym z dnia 15 listopada 1984 r. (Dz.U. z 1993 r. Nr 94, poz. 431 z późn. zm.).
} 
przewaloryzowania współczynnikami przeliczeniowymi gruntów na hektary przeliczeniowe (podatkowe) [Gruziel 2008, s. 57]. Opodatkowaniu podlegaja więc grunty o odpowiedniej klasyfikacji zawartej w ewidencji gruntów i budynków. Podstawę opodatkowania stanowi liczba hektarów fizycznych lub przeliczeniowych, które wynikają ze wspomnianej ewidencji. Oznacza to, że opodatkowaniu tym podatkiem podlegają wszystkie użytki rolne oraz grunty zadrzewione i zakrzewione na tych użytkach, bez względu na ich powierzchnię, dochodowość czy też położenie ${ }^{4}$.

Kryterium wymiaru podatku rolnego to:

- powierzchnia gruntów, które podlegają opodatkowaniu,

- jakość i rodzaj użytków rolnych,

- położenie gospodarstwa (okręgi podatkowe),

- normy hektarowe,

- stałe stawki podatku,

- zwolnienia i ulgi.

Z kolei za kryteria ekonomiczne wymiaru podatku rolnego [Podstawka 2000, s. 52-53] uważa się: wartość użytkową, normy określające wartość użytkowa, normy hektarowe, okręgi podatkowe, stawki podatkowe, ulgi i zwolnienia. Użytki rolne podlegające opodatkowaniu wyodrębnione w ewidencji to grunty orne, sady, łąki trwałe, pastwiska trwałe, grunty rolne zabudowane, grunty pod stawami, rowy. Wysokość podatku rolnego w każdym roku jest inna i jest ona zależna od ceny jednego q żyta określanego w komunikacie prezesa GUS.

Do wad tego rozwiązania najczęściej zalicza się traktowanie podatku rolnego jako podatku uniwersalnego [Wyszkowska 2006, s. 180-186]. Niestety daje on możliwości różnych spekulacji przez osoby chcące wykorzystać niskie obciążenia podatkowe. Odbywa się to poprzez nabywanie gruntów przez osoby nieprowadzące działalności rolniczej w celach spekulacyjnych lub korzystanie $\mathrm{z}$ dopłat lub preferencji przewidzianych dla rolników. Innym sposobem jest „sztuczne” powiększanie posiadanych obszarów rolnych celem obniżenia wysokości podatku rolnego.

Według rolników, obowiązujący podatek rolny jest sprawiedliwy, chociaż niektórzy z nich proponują zmianę zasad określania współczynników przeliczeniowych. Wśród badanych są także głosy postulujące zmianę nieodpowiednio dobranych okręgów podatkowych. Rolnicy, zwłaszcza starsi wiekiem, boją się zmian, a przede wszystkim wprowadzenia obowiązku dodatkowych ewidencji i rozliczeń.

\footnotetext{
${ }^{4}$ Rozwiązanie to wprowadzono zmianą ustawy o podatku rolnym z dnia 10 października 2002 r. (Dz.U. z 2002 r., Nr 200, poz. 1680).
} 


\section{Propozycje zmian w opodatkowaniu gospodarstw rolnych}

Wielu rolników nie aprobuje zaproponowanych zmian w opodatkowaniu ich działalności. Ustawodawca twierdzi, że wprowadzenie podatku dochodowego w zamian za podatek rolny nie powinno powodować znacznego zwiększenia obciążeń rolników, ale według rolników, tak niestety nie będzie. Wysokość nowego podatku powinna zostać tak określona, aby była neutralna dla rolników. Proponowanym podatkiem dochodowym obciążone mają zostać tylko te większe gospodarstwa rolne i to one będą miały obowiązek ewidencji w księgach rachunkowych.

W projekcie Ministerstwa Finansów dokonano podziału rolników na uboższych i tych bardziej zamożnych, tzn. tych, których przychody przekraczałyby 100 tys. zł w roku gospodarczym ${ }^{5}$. Grupa uboższych rolników miałaby zostać zwolniona $\mathrm{z}$ podatku dochodowego, ale zmuszona byłaby do płacenia podatku od nieruchomości (na zasadach podobnych do obecnego podatku rolnego, czyli określoną stawkę od hektara przeliczeniowego). Ministerstwo proponuje określone stawki tego podatku, a ponadto próbuje wymusić zagospodarowanie nieużytków, stosując ich opodatkowanie stawką za hektar dwukrotnie wyższą niż w przypadku podatku od nieruchomości ${ }^{6}$. Dla celów tych podatków rolnicy będą zmuszeni do prowadzenia odpowiednich ewidencji przychodów.

$\mathrm{Na}$ wzór opodatkowania działalności gospodarczej, w stosunku do gospodarstw rolnych osiagających wyższe przychody, Ministerstwo Finansów chce wprowadzić zróżnicowany sposób opodatkowania. Rolnicy posiadaliby możliwość wyboru zryczałtowanej formy opodatkowania w postaci funkcjonującego obecnie tzw. ryczałtu od przychodów ewidencjonowanych ${ }^{7}$. Wprowadzony limit przychodu ograniczający możliwość stosowania tego ryczałtu to 150 tys. euro w roku poprzednim, a zaproponowana stawka opodatkowania wynosi 4\%. Przychody wyższe podlegałyby opodatkowaniu na zasadach ogólnych.

Do przychodów z gospodarstw rolnych proponowany projekt przewiduje zaliczenie przychodów z agroturystyki, ze sprzedaży produktów rolnych, a także przychody rolników prowadzących tzw. małe przetwórstwo. $Z$ całą pewnością do przychodów nie będą zaliczane dopłaty do ubezpieczeń rolniczych, dopłaty do paliwa rolniczego czy dopłaty bezpośrednie.

\footnotetext{
${ }^{5}$ Rok obrotowy przyjmuje się inny niż kalendarzowy, a więc od 1 lipca do 30 czerwca następnego roku.

${ }^{6}$ Założenia do projektu ustawy o zmianie ustawy o podatku dochodowym od osób fizycznych, ustawy o podatku dochodowym od osób prawnych, ustawy o zryczałtowanym podatku dochodowym od niektórych przychodów osiąganych przez osoby fizyczne, ustawy o podatku rolnym, www.bip.kprm.gov.pl (data dostępu: 12.01.2014).

7 Tamże.
} 
Podobnie jak podatnicy podatku dochodowego sektora MSP, właściciele gospodarstw rolnych mieliby możliwość odliczania składek na ubezpieczenia społeczne, a także korzystania $\mathrm{z}$ odliczeń, ulg przewidzianych dla podatników podatku dochodowego od osób fizycznych.

W projekcie przewiduje się złagodzenie okresu wejścia podatku dochodowego w postaci zastosowania limitów dochodów celem ustalenia sposobu obliczania podatków. Ustawodawca stara się wprowadzić okres przejściowy pomagający rolnikom przystosować się do nowych zasad opodatkowania. Propozycje okresu przejściowego przyjmują limit dochodów i tak na przykład w 2015 roku w wysokości do 200 tys. zł, a w 2016 roku 150 tys. zł ${ }^{8}$. Za podstawę ustalania tych limitów powinny zostać uznane przychody z poprzedniego roku gospodarczego.

Wśród badanych, którzy nie są przeciwni wprowadzeniu podatku dochodowego, zdania na temat zasad naliczania proponowanego podatku są podzielone. Większość jednak stwierdza, że wysokość obciążenia podatkowego powinna być uzależniona od dochodu, po uwzględnieniu kosztów pracy rolnika oraz jego rodziny. Ponadto badani wysuwają postulaty uzależnienia wysokości opodatkowania od areału oraz warunków klimatyczno-glebowych. Oczywiście wśród badanych przeważają rolnicy przeciwni wprowadzeniu podatku dochodowego w rolnictwie. Według nich, obecny podatek rolny jest prosty, sprawiedliwy i nie podlega spekulacjom. Odnosząc się do badań w okresach poprzednich, liczba rolników przeciwnych wprowadzeniu nowych rozwiązań w podatkach w rolnictwie uległa nieznacznemu zmniejszeniu.

Według szacunków Ministerstwa Finansów, proponowanym podatkiem dochodowym objętych zostałoby około 120 tys. gospodarstw, a pozostałe $(1,8 \mathrm{mln})$ korzystałyby ze zwolnienia $\mathrm{z}$ tego podatku, ale miałyby one obowiązek płacenia podatku od nieruchomości ${ }^{9}$. Być może z powodu faktu, że tak duża grupa rolników korzystałaby ze zwolnień, przyjęcie zmian w opodatkowaniu gospodarstw rolniczych nie budzi już takich emocji.

Niestety, o ile podatek rolny nie podlegał dyskusji i miał jasne reguły naliczania (chociaż też podlegał spekulacjom), to podatek dochodowy może już podlegać większemu „sterowaniu” przez podatnika. To, jakie koszty i jakiej wysokości przychody ujawni podatnik może zależeć tylko od rolnika. Część przychodów, zwłaszcza ze sprzedaży dla sfery detalicznej, może zostać nie zarejestrowana w księgach rachunkowych lub innej ewidencji. Podobnie część kosztów dotycząca sfery życia prywatnego rolnika, która może zostać zaksięgowana w koszty prowadzonej działalności. Propozycja zwolnienia tej największej

\footnotetext{
8 Tamże.

9 Tamże.
} 
grupy z podatku dochodowego zapobiegnie w znacznym stopniu „zabiegom” obniżania obciążeń podatkowych.

Patrząc na rozwiązania opodatkowania działalności rolniczej w innych krajach, należałoby stwierdzić, że w większości z nich traktuje się tę działalność pod względem opodatkowania tak samo, jak pozostałą działalność gospodarczą. W opodatkowaniu działalności rolniczej spotykamy niemal wszystkie rodzaje podatków: podatek dochodowy od osób fizycznych, podatek dochodowy od osób prawnych, podatek gruntowy, podatek majątkowy, podatek VAT i oczywiście wiele innych podatków lokalnych ${ }^{10}$. Podobnie jak przy rozliczaniu działalności gospodarczej, rolnicy mogą korzystać z wielu różnych ulg, uproszczeń, zwolnień pozwalających na obniżenie płaconych podatków. W krajach takich jak Austria, Niemcy, Włochy i Francja stosowane są preferencyjne formy opodatkowania działalności rolniczej. Przy okazji omawiania podatków należy wspomnieć, że dopłaty bezpośrednie i różnego rodzaju dotacje w wielu krajach podlegają opodatkowaniu (Francja, Holandia, Węgry) ${ }^{11}$, ale są i takie kraje, które zwalniają je z opodatkowania (Niemcy) lub stosują stawki preferencyjne (Belgia).

Różnice w sposobie opodatkowania w krajach UE są wynikiem różnego podejścia do określania dochodu. Może to się odbywać na podstawie ewidencji rachunkowości uproszczonej bądź pełnej, a nawet średniej dochodu z kilku wcześniejszych lat. W niektórych krajach dochód gospodarstw rolnych może być ustalany kilkoma metodami: na podstawie ksiąg rachunkowych, uproszczonej rachunkowości, na podstawie ekonomicznej wartości gruntu (metoda liniowa), a także na podstawie wyceny przez organy skarbowe w przypadkach, kiedy nie można zastosować żadnej z metod. W przypadku stawek podatku dochodowego, różnice te wynikają ze stosowania specyficznych, odrębnych form opodatkowania dla dochodów gospodarstw rolnych w poszczególnych krajach, jednak w ramach systemów podatkowych poszczególnych krajów stawki są z reguły podobne i dla działalności gospodarczej, i dla działalności rolniczej.

Czy zastapienie podatku rolnego dochodowym będzie neutralne trudno powiedzieć, patrząc na wyniki badań Gruziel [2008, s. 147-173] biorącej za podstawę ewidencję FADN w niektórych regionach Polski. Z badań tych wynika, że zastapienie podatku rolnego podatkiem dochodowym $w$ regionach Mazow-

\footnotetext{
${ }^{10}$ USA - podatki: PDOF, PDOP, podatek od sprzedaży, podatki lokalne. Francja - PDOF, PDOP, podatek gruntowy, majątkowy, podatki lokalne i VAT. Niemcy - podobnie jak Francja, ale podatek majątkowy ma charakter katastralny i jest włączony do podatku gruntowego.

11 Rozporządzenie Rady (WE) nr 73 (24) z dnia 19 stycznia 2009 r. „Płatności przewidziane w ramach wspólnotowych systemów wsparcia powinny być przekazywane przez właściwe organy krajowe beneficjentom w pełnej wysokości - z zastrzeżeniem jakichkolwiek zmniejszeń przewidzianych w niniejszym rozporządzeniu - oraz w określonych terminach".
} 
sza i Podlasia byłoby niekorzystne z uwagi na niższą jakość gleb, a więc niższy podatek rolny niż w pozostałych badanych regionach (Wielkopolska, Śląsk). W przypadku tych drugich również podatek rolny jest niższy niż hipotetyczny podatek dochodowy. Oczywiście przy większych dochodach gospodarstw różnica $\mathrm{w}$ wielkościach omawianych podatków będzie zdecydowanie większa na korzyść podatku rolnego.

\section{Przyszłość rachunkowości w gospodarstwach rolnych}

Rachunkowość gospodarstw rolniczych istniała i nadal istnieje, mimo że rolnicy nie mają obowiązku jej prowadzenia. Już w 1907 roku pojawiają się pierwsze informacje o polskiej rachunkowości rolniczej, a dokładniej jej potrzebie prowadzenia ${ }^{12}$. Już wtedy dostrzegano potrzebę prowadzenia ewidencji księgowej między innymi po to, aby określić liczbowo wielkość majątku gospodarstwa, wykazać jego efektywność itp. Bez odpowiedniej ewidencji jest to utrudnione. Musiał minąc wiek, aby pojawiła się szansa wprowadzenia takiego obowiązku. Oczywiście rolnicy mogą z własnej inicjatywy prowadzić różnego rodzaju ewidencje ${ }^{13}$. Część z nich dobrowolnie uczestniczy w programie FADN, prowadząc rachunkowość swoich gospodarstw pod opieką IERGiŻ. Według wielu rolników, jest ona jednak mało przejrzysta, mało czytelna i nie oferuje informacji będącej przedmiotem zainteresowania rolników ${ }^{14}$. Należałoby również zaznaczyć wrodzoną niechęć rolników do gromadzenia dokumentacji, ujawniania części dochodów, brak wiedzy na temat prowadzenia ewidencji itp.

Wprawdzie rachunkowość rolnicza ma tradycję wielowiekową, tak, jak rachunkowość klasyczna, ma jednak nieco szerszy zasięg zainteresowania. W jej skład zalicza się ewidencję księgową, sprawozdawczość, a także pozaksięgowe obliczanie kosztów. Obecnie zaczęto analizę działalności rolniczej traktować jako oddzielną dyscyplinę naukową i praktyczną, podobnie jak kalkulacje rolnicze, które pierwotnie wchodziły w skład rachunkowości rolniczej, a obecnie zalicza się je do elementów rachunku ekonomicznego w gospodarstwach rolnych.

\footnotetext{
12 Rolnik Jan Kopecki (region Poznania) w swoim referacie postawił pytanie: „Dlaczego i jak powinien gospodarz rachować?".

${ }^{13}$ W 1926 roku wprowadzono rachunkowość laurowską ze Szwajcarii (inż. J. Cużytko). Przetrwała ona okupację i jest nadal prowadzona przez niektórych rolników, [za:] Bernacki A., Informatyka $w$ gospodarstwie rolniczym, referat na konferencji „Nowoczesne techniki informacyjne w nauce, edukacji i doradztwie dla wsi i rolnictwa, 16-18.09.2004 r. Brwinów-Warszawa.

${ }^{14}$ Opinie wypowiadane przez rolników podczas przeprowadzanych badań.
} 
Czy rachunkowość gospodarstw rolnych jest inna od tej klasycznej? Zarówno w rachunkowości działalności gospodarczej, jak i w rachunkowości gospodarstw rolnych celem jest pomiar, gromadzenie i przetwarzanie informacji o procesach zachodzących $w$ danej jednostce gospodarczej czy też organizacyjnej [Goraj i in. 2004, s. 12-17]. Podobnie można wyróżnić w niej rachunkowość finansową, rachunkowość zarządczą, a także rachunkowość podatkową, która może być traktowana jako odmiana rachunkowości finansowej.

Wielu rolników może się zastanawiać nad sensem stosowania rachunkowości zarządczej w swoich gospodarstwach, ale w dobie gospodarki rynkowej jest ona potrzebna do prawidłowego funkcjonowania gospodarstwa. Do skutecznego zarządzania gospodarstwem niezbędna jest wiedza i rozumienie zasad planowania, funkcjonowania gospodarstwa rolnego, ograniczeń, efektywności i skuteczności realizacji wytyczonych celów, umiejętność analizy informacji z ewidencji księgowej. Jakość informacji z rachunkowości jest niezbędnym elementem procesów zarządzania, bez względu na rodzaj prowadzonej działalności, dlatego dołożenie starań o tę jakość wpłynie na eliminację błędów w zarządzaniu i zapewni skuteczne zarządzanie. Wniosek nasuwa się sam - bez ewidencji, bez informacji z rachunkowości nie można skutecznie zarządzać.

Rachunkowość nie stanowi obowiązku dla gospodarstw rolnych, z wyjątkiem tych, które prowadzą działy specjalne produkcji rolnej oraz dodatkową działalność gospodarcza. W przypadku tych drugich, mogą one prowadzić uproszczoną ewidencje, jeśli ich gospodarstwo posiada ponad 1 ha powierzchni, a działalność gospodarcza przynosi przychód roczny do 10 tys. zł i jest wykonywana osobiście lub z udziałem członków rodziny. Ewidencja ta ma nazwę PKPiRPdR (Podatkowa Księga Przychodów i Rozchodów Przeznaczona dla Rolników) - jest to prosta ewidencja uwzględniająca tylko kategorie: przychód, koszt i dochód.

O ile sama rejestracja w księgach nie nastręcza wiele problemów w przypadku ewidencji uproszczonej, to jednak pojawia się wiele pytań o inne elementy związane z jej prowadzeniem. Do tych problemów należą między innymi:

- wycena zapasów, produktów i ich inwentaryzacja,

- kwestia dokumentacji niektórych operacji gospodarczych (sprzedaż na targowiskach, w gospodarstwie itp.)

- wycena pracy własnej i członków rodziny,

- rozdzielenie kosztów prywatnych i służących działalności rolniczej,

- określenie roku obrotowego,

- wiele innych, z którymi rolnik będzie musiał sobie poradzić.

Bez jasnego sprecyzowania wielu problemów związanych $\mathrm{z}$ ewidencja i zakwalifikowaniem kosztów do tzw. kosztów uzyskania przychodów rolnicy będą borykać się, podobnie jak większość przedsiębiorców, z udowodnieniem faktu konieczności poniesienia określonego kosztu przed kontrolą skarbową. 
Subiektywne podejście urzędników do niektórych kategorii i niektórych elementów działalności rolniczej spowoduje poczucie krzywdy, niesprawiedliwości wśród właścicieli gospodarstw nieprzywykłych do kontaktów z nimi. Wielu przedsiębiorców, którzy od lat prowadzą działalność, nie radzi sobie z problemem rozliczania swojej działalności, a cóż dopiero rolnicy, którzy nie są przyzwyczajeni do prowadzenia ewidencji i rozliczania jej przed organami podatkowymi.

Większość gospodarstw rolnych w Polsce nie ma zwyczaju prowadzenia rejestrów wpływów i wydatków, nie mówiąc już o szacowaniu dochodowości i opłacalności swojej działalności. Rolnicy, tak jak kiedyś właściciele przedsiębiorstw sektora MSP, decyzje podejmują bardziej intuicyjnie niż na podstawie jakichkolwiek analiz. Często pod wpływem obserwacji otoczenia, doradztwa sąsiedzkiego itp. Brak stosowania jakiejkolwiek ewidencji (księgowości), przyzwyczajenia, emocje lub sentymenty przy podejmowaniu decyzji skutkują bardzo często negatywnymi wynikami.

Rząd podejmując decyzje o opodatkowaniu podatkiem dochodowym ma do dyspozycji kilka metod ewidencji działalności rolniczej. Może wykorzystać już istniejące metody, takie jak:

- ryczałt od przychodów ewidencjonowanych - ewidencja tylko przychodów,

- karta podatkowa - brak obowiązku ewidencji, podatek naliczany według określonego kryterium, np. wielkość areału lub rodzaj produkcji,

- przychód pomniejszony o koszty ryczałtowe - ewidencja przychodów, koszty określone procentowo lub kwotowo, opodatkowanie liniowe lub w określonej skali,

- przychód pomniejszony o poniesione koszty rzeczywiste, w tym inwestycje (PKPiR lub księgi rachunkowe) - zasady obowiązujące w działalności gospodarczej (progresywny lub liniowy sposób opodatkowania).

Kwestia jest tylko wyznaczenie górnego pułapu przychodów, tak jak to ma miejsce $\mathrm{w}$ działalności gospodarczej dla każdej z tych metod. W przypadku niektórych z tych metod można byłoby zastosować swobodę decyzji, co do wyboru formy ewidencji i opodatkowania. Należałoby również uwzględnić kwestię klęski nieurodzaju, której ryzyko nie jest zależne od rolnika.

Wśród sektora MSP najczęściej stosowaną formą ewidencji jest uproszczona jej forma w postaci podatkowej księgi przychodów i rozchodów. Pozwala ona przedsiębiorcom od uzyskanych przychodów odliczyć poniesione koszty, a jednocześnie jest to niezbyt pracochłonna forma ewidencji ograniczona górnym limitem obrotów ze sprzedaży, po przekroczeniu którego przedsiębiorstwo ma obowiązek prowadzić księgi rachunkowe.

W UE stosowane są podobne do tych funkcjonujących w działalności gospodarczej formy ewidencji i opodatkowania, chociaż rolnicy nie mają obowiązku 
prowadzenia rachunkowości. Niektóre z państw stosują odmienne rozwiązania ${ }^{15}$, jednak w przypadku działalności rolniczej o znacznych dochodach oraz osób prawnych nie dopuszczają możliwości uproszczonych ewidencji i korzystania z ulg czy przywilejów.

\section{Biura rachunkowe a rachunkowość gospodarstw rolnych}

Istniejący obecnie podatek rolny nie nastręcza rolnikom problemów z rozliczaniem się $\mathrm{z}$ administracją samorządową gdyż jest on przez nią naliczany, a rolnik ma tylko obowiązek zapłaty wyliczonej przez urząd kwoty. Po zmianie sposobu opodatkowania z podatku rolnego na podatek dochodowy rolnicy będą mieli obowiązek prowadzenia ewidencji prowadzonej działalności. W zależności od wielkości osiaganych dochodów może to być albo uproszczony sposób ewidencji, albo ewidencja pełna w postaci ksiag rachunkowych.

Zasada ewidencji (rachunkowości) dla wszystkich osób i organizacji korzystających $\mathrm{z}$ dopłat jest obecnie przedmiotem prac w UE, stąd prawdopodobnie będzie wynikał obowiązek prowadzenia rachunkowości również w gospodarstwach rolnych. Wynika to $\mathrm{z}$ faktu, że rolnictwo jest jedną z form prowadzenia działalności gospodarczej.

W Polsce proponowane zmiany zasad opodatkowania działalności rolniczej przewiduja, że znaczna grupa rolników zwolniona zostanie z podatku dochodowego, a więc i prawdopodobnie z ewidencji, ale patrząc na poczynania Unii Europejskiej może dojść do sytuacji, gdy chcąc korzystać z dopłat, rolnicy zmuszeni zostaną do prowadzenia rachunkowości [Różańska i Terlecki, www].

Obecnie większość rolników nie prowadzi żadnych ewidencji, a z badań wynika ${ }^{16}$, że zaledwie $5 \%$ rolników prowadzi uproszczone rozliczenia działalności swoich gospodarstw (tab. 1).

Wśród badanych tylko $2 \%$ zgłosiło dobrowolny ewentualny akces prowadzenia rachunkowości w ramach programu FADN. Pozostali rolnicy nie widzą potrzeby prowadzenia jakichkolwiek rozliczeń. W przypadku wprowadzenia

\footnotetext{
${ }^{15}$ Wielka Brytania - nakaz prowadzenia rachunkowości zamiast amortyzacji; odlicza się rocznie od dochodu $40 \%$ kosztów inwestycji, a straty w ciągu 5 lat - te zasady dotyczą tylko osób fizycznych. Francja - jeśli rolnik prowadzi księgi rachunkowe może uzyskać $20 \%$ ulgi, stosować uproszczone formy ewidencji (do 76 tys. euro przychodu), a straty rozliczać przez 6 lat, może także ustalać dochód jako średnią dochodu z 3 lat.

${ }^{16}$ Badania własne na grupie 120 osób (rolników i właścicieli biur rachunkowych) w województwach mazowieckim, łódzkim i podlaskim w okresie od listopada 2013 roku do lutego 2014 roku.
} 
Tabela 1

Wybrane elementy badań wśród gospodarstw rolnych

\begin{tabular}{|c|l|c|}
\hline Lp. & Pytanie ankietowe & Wyniki [\%] \\
\hline 1 & Czy jest Pan/Pani skłonny do dobrowolnego prowadzenia rachunkowości? & 2 \\
\hline \multirow{3}{*}{2} & Kto będzie prowadził ewidencję w Pana/Pani gospodarstwie: & \\
& - samodzielnie, & 78 \\
& - rodzina lub znajomi, & 7 \\
& - platforma internetowa. & 1 \\
\hline \multirow{2}{*}{3} & Czy jest Pan/Pani skłonny uczestniczyć w szkoleniach z zakresu rachun- & 28 \\
\cline { 2 - 3 } & kowości? & 28 \\
\hline
\end{tabular}

Źródło: Opracowanie na podstawie badań własnych.

obowiązkowej ewidencji działalności rolniczej około 78\% rolników stanowczo opowiada się za prowadzeniem jej przez biura rachunkowe. Około 7\% poszuka pomocy wśród rodziny i znajomych, a zaledwie $1 \%$ skorzysta z platform internetowych oferujących możliwość samodzielnego prowadzenia uproszczonych ewidencji. Pozostali badani nie mają jeszcze zadania, tym bardziej że nie maja pewności czy wprowadzony zostanie obowiązek prowadzenia rachunkowości. Wśród badanych około $28 \%$ planuje odbyć szkolenia dotyczące prowadzenia ewidencji działalności rolniczej.

Biura rachunkowe muszą się również przygotować do przejęcia obsługi rachunkowej indywidualnych gospodarstw rolnych. Problem będzie polegał między innymi na tym, jaką część ponoszonych kosztów zaliczyć do działalności gospodarczej, a jaką do wydatków prywatnych. Niezwykle ważne jest określenie $\mathrm{w}$ ustawie sposobu postępowania $\mathrm{w}$ tego rodzaju przypadkach, gdyż podczas kontroli może być zastosowane subiektywne podejście kontrolującego, a przez to często krzywdzące rolnika. Mogą zdarzyć się również odwrotne sytuacje, czyli takie, w których podatnicy nadużywają prawa do odliczania kosztów od przychodów i nawet koszty dotyczące sfery życia prywatnego zaliczają do kosztów działalności, zmniejszając podstawę opodatkowania. Biura zostaną postawione przed decyzją, czy reprezentować interesy swoje, dbając o dobro klienta, czy też reprezentować interesy państwa, tracąc klientów, ale nie narażając się na konsekwencje karne. Inną kwestią będzie między innymi dokumentacja niektórych zdarzeń gospodarczych, zaliczenie środków trwałych do tych służących działalności rolniczej i tych, które są tylko częściowo używane w tej działalności (np. samochód), ich amortyzacji itp.

Wprowadzenie obowiązku prowadzenia ewidencji działalności rolniczej może spowodować konieczność powstania biur rachunkowych w obszarach wiejskich. Już teraz liczba funkcjonujących biur rachunkowych jest znaczna (tab. 2), a liczba osób uprawnionych do świadczenia usług prowadzenia ksiąg 
Tabela 2

Zmiany strukturalne biur rachunkowych według grup zatrudnienia w latach 2005-2013

\begin{tabular}{|c|c|c|c|c|c|}
\hline \multirow{2}{*}{ Okres } & Liczba biur & \multicolumn{4}{|c|}{ Wielkość biura rachunkowego według liczby zatrudnionych } \\
\cline { 3 - 6 } & rachunkowych & $0-9$ & $10-49$ & $50-249$ & $<250$ \\
\hline 2005 & 35340 & 34450 & 808 & 70 & 12 \\
\hline 2006 & 35825 & 34910 & 834 & 69 & 12 \\
\hline 2007 & 36509 & 35552 & 877 & 69 & 11 \\
\hline 2008 & 37351 & 36239 & 1034 & 63 & 15 \\
\hline 2009 & 38901 & 37684 & 1130 & 68 & 19 \\
\hline 2010 & 42348 & 41075 & 1185 & 67 & 21 \\
\hline 2011 & 43401 & 42107 & 1204 & 72 & 18 \\
\hline 2012 & 44987 & 43792 & 1114 & 63 & 18 \\
\hline 2013 & 46243 & 45047 & 1113 & 63 & 20 \\
\hline
\end{tabular}

Źródło: Opracowanie własne na podstawie danych GUS za lata 2005-2013.

rachunkowych co roku wzrasta i obecnie wynosi około 120 tys., biorąc pod uwagę także profesje biegłych rewidentów i doradców podatkowych ${ }^{17}$.

Ponad 96\% tych biur rachunkowych to osoby fizyczne, a największa liczba biur funkcjonuje w województwach mazowieckim (10 125), śląskim (5215), wielkopolskim (4779), a najmniejsza w podlaskim, lubuskim i świętokrzyskim ${ }^{18}$.

Właściciele biur rachunkowych do zmian podchodzą ze spokojem. Wprawdzie widzą szansę w rozszerzeniu swojej oferty o usługi prowadzenia rachunkowości dla gospodarstw rolnych i starają się przygotować do przejęcia tego rynku usług, ale równocześnie uważaja, że raczej nie zdecydują się na podnoszenie cen swoich usług z uwagi na ewentualny zwiększony popyt na rynku usług finansowo-księgowych. Ponad 39\% z badanych biur rachunkowych ma nadzieję na pozyskanie dodatkowych klientów (gospodarstw rolnych) i ma zamiar w przyszłości poszerzyć teren swojego działania na obszary wiejskie, wykorzystując dostęp do Internetu. Około 48\% właścicieli badanych biur rachunkowych już stara się pozyskać wiedzę dotyczącą prowadzenia rachunkowości gospodarstw rolnych, pozostali z badanych nie widzą jeszcze potrzeby przygotowań do świadczenia takich usług.

\footnotetext{
${ }^{17}$ Certyfikaty księgowe - 65 200, świadectwa kwalifikacyjne wydawane do 2002 roku - 34787 (stan na 31.03.2014).

${ }^{18}$ Zobacz szerzej: E. Klamut, 2012: Perspektywy i kierunki rozwoju rynku ustug finansowo-księgowych, [w:] Antoszkiewicz J. (red.), M. Dębski, Problemy Zarzadzania, Przedsiębiorczość: Zarządznie, Tom XIII, Zeszyt 15, Społeczna Akademia Nauk, Łódź, s. 42-58, oraz E. Klamut, 2013: Wptyw kryzysu na rynek ustug finansowo-księgowych, [w:] Brendzel-Skowera K. (red.), Wyzwania i perspektywy wspótczesnego zarzqdzania. Innowacje, kryzys, przedsiębiorczość, Wydawnictwo Politechniki Częstochowskiej, Częstochowa.
} 


\section{Podsumowanie}

W przekonaniu dużej liczby rolników zastąpienie podatku rolnego podatkiem dochodowym spowoduje zwiększenie obciążeń ich działalności rolniczej. Formy ryczałtowe zmniejszą konieczność pełnej ewidencji działalności, ale z pewnością zwiększą obowiązki związane $\mathrm{z}$ rozliczaniem. W tym przypadku rolnicy będą mogli skorzystać $\mathrm{z}$ outsourcingu finansowo-księgowego, bądź też zatrudnić osobę z odpowiednią wiedzą lub nabyć wiedzę przez odbycie odpowiednich szkoleń w tym zakresie.

Jeśli wprowadzony zostanie podatek dochodowy w formie progresywnej, będzie on odpowiedni dla gospodarstw o wysokich kosztach i niskich dochodach, przynoszących niskie dochody lub nawet straty. Formy ryczałtowe nie zawsze są opłacalne, patrząc przez analogię do form opodatkowania działalności gospodarczej. Stosowany w działalności gospodarczej podatek liniowy odpowiedniejszy byłby dla gospodarstw wyspecjalizowanych, o wyższych dochodach, o intensywniejszej produkcji. Proponowane wprowadzenie podatku od nieruchomości i zwolnienie małych jednostek rolniczych z podatku dochodowego jest zastapieniem podatku rolnego i nie powinno obciążyć dodatkowymi kosztami „małych rolników".

Podobnie jak w innych krajach UE, rolnicy powinni mieć możliwość wyboru z pośród kilku wariantów opodatkowania tak, aby mogli zoptymalizować opodatkowanie własnej działalności.

Problemem dla rolników może być wprowadzenie obowiązku prowadzenia ewidencji w gospodarstwach korzystających $\mathrm{z}$ dopłat, nad którym pracuje UE. Obecnie wielu rolników korzysta z dopłat, ale czy przy uwarunkowaniu prowadzenia rachunkowości nie zmienią zdania, czy nie ucierpi na tym rozwój gospodarstw? I tak, i nie. Osoby w sposób uczciwy prowadzący swoje gospodarstwa nie będą się bać tego obowiązku, a pozostali albo zrezygnują z dopłat, albo znajdą możliwość obejścia tych przepisów.

Przeprowadzane badania w niektórych regionach Polski wśród indywidualnych gospodarstw rolnych o intensywnej produkcji rolnej wskazują [Forfa 2011, s. 87-101], że opodatkowanie podatkiem dochodowym może spowodować obniżenie dochodowości, a tym samym zmniejszenie nakładów na modernizację gospodarstw i intensyfikację produkcji.

Następnym problemem związanym z rolnictwem są coraz częstsze anomalie pogodowe, które w znaczący sposób zmniejszają w ostatnich latach dochody sporej grupy rolników. Ten problem klęsk żywiołowych powinien być uwzględniany w działalności rolniczej bądź to przez ubezpieczenia, bądź przez ulgi w obciążeniach podatkowych. 
Nikt nie lubi zmian, a z całą pewnością tych, które nie wiadomo, co przyniosa. Czy wygra budżet, czy wygrają rolnicy, a może wszyscy? Na rezultat tych zmagań musimy nieco poczekać. Ważne jest, aby wprowadzane zmiany były przemyślane. Od rolników będzie zależeć, jak sobie poradzą.

\section{Literatura}

BERNACKI A., 2004: Infromatyka w gospodarstwie rolniczym, Konferencja „Nowoczesne techniki informacyjne w nauce, edukacji i doradztwie dla wsi i rolnictwa, 16-18.09.2004 r., Brwinów-Warszawa.

FORFA M., 2011: Obciqżenia fiskalne gospodarstw rolniczych $w$ zależności od wielkości ekonomicznej oraz typu rolniczego, Zeszyty Naukowe SGGW w Warszawie, EiOGŻ 92.

GORAJ L., MAŃKO S., SASS R., WYSZKOWSKA Z., 2004: Rachunkowość rolnicza, Wydawnictwo Difin, Warszawa.

GORAJ L., MAŃKO S. (red.), 2009: Rachunkowość i analiza w indywidualnym gospodarstwie rolnym, Wydawnictwo Difin, Warszawa.

GRUZIEL K., 2008: Stan i kierunki zmian w opodatkowaniu gospodarstw rolniczych, Wydawnictwo SGGW, Warszawa.

KLAMUT E., 2012: Perspektywy i kierunki rozwoju rynku ustug finansowo-księgowych, [w:] Antoszkiewicz J. (red.), M. Dębski, Problemy zarzadzania, Przedsiębiorczość i Zarządzanie, Tom XIII, Zeszyt 15, Społeczna Akademia Nauk, Lódź.

KLAMUT E., 2013: Wplyw kryzysu na rynek ustug finansowo-księgowych, [w:] BrendzelSkowera K. (red.), Wyzwania i perspektywy współczesnego zarzqdzania. Innowacje, kryzys, przedsiębiorczość, Wydawnictwo Politechniki Częstochowskiej, Częstochowa.

PODSTAWKA M., 2000: System podatkowy w rolnictwie, Wydawnictwo SGGW, Warszawa.

RÓŻAŃSKA E., TERLECKI J., Rachunkowość rolna instrumentem ksztattowania zdolności konkurencyjnej gospodarstw rolnych, www.wodr.poznan.pl (data dostępu: 12.01.2014).

WYSZKOWSKA Z., 2006: Rachunkowość w przedsiębiorstwach rolniczych, Wydawnictwo Difin, Warszawa.

Ustawa z dnia 10 października 2002 r. o podatku rolnym (Dz.U. z 2002 r. Nr 200, poz. 1680).

Ustawa z dnia 29 listopada 2000 r. o zbieraniu i wykorzystywaniu danych rachunkowych z gospodarstw rolnych. (Dz.U z 2000 r. Nr 3, poz. 20 ze zm.)

Założenia do projektu ustawy o zmianie ustawy o podatku dochodowym od osób fizycznych, ustawy o podatku dochodowym od osób prawnych, ustawy o zryczałtowanym podatku dochodowym od niektórych przychodów osiaganych przez osoby fizyczne, ustawy o podatku rolnym, www.bip.kprm.gov.pl (data dostępu: 12.01.2014). 


\title{
Taxation and accountancy of agricultural farm activities
}

\begin{abstract}
Foreshadowed introduction of income tax on agricultural farm activities has caused an avalanche of questions on: how should records and accounting of economic events in these farms be kept? Is it profitable for farmers or should it rather plunge them? Is agricultural tax more suitable than income tax? The article is an attempt to answer some of the nagging questions on the basis of researching legal acts, opinions of experts and those most interested - farmers.
\end{abstract}


